\title{
"The greatest and deepest quarry of emotions ever known": The Holocaust Memorial Project
}

\author{
Kayla Lorenzen, Siobain Quinton, Keelan Sinnott, Emily Turcato and Neil \\ Zimmerman
}

This essay was the winning submission in a classroom competition to construct a public Holocaust memorial in Calgary, Alberta, Canada. Three groups were tasked with critically analyzing the history of Holocaust memorialization in order to detail the unique challenges surrounding Holocaust memorialization. Furthermore, the assignment required a description of the proposed monument from each group, along with an argument justifying the specific design choices and goals of the monuments. Each monument proposal was presented in turn before the classroom and then judged by professors Dr. Scott Murray and Dr. Tom Brown, and critiqued by peers.

***

The development of historical monuments designed to commemorate and memorialize memory is problematic for many reasons. The purpose of this proposal is to address a number of decisions and considerations associated with designing a Holocaust monument in the city of Calgary, Alberta, Canada. Specifically, this proposal will address who the monument is designed to commemorate, where the monument will be located, the maintenance and materials of the monument, and what feeling the monument is intended to convey to those who visit it. Ultimately, our proposed monument confronts and evidences the uncomfortable legacy and nature of the Holocaust rather than attempting to avoid or displace it, and is designed to elicit appreciation for peace in Calgary, as well as to question it.

The Holocaust is regarded as a particularly difficult historical event to come to terms with, existing as a rupture within the vaunted concept of progress that Western civilization has held so dear. As an undoubtedly dark chapter in the history of Western civilization, what some have even argued was a twisted outcome of the Enlightenment ideals of rationality and progress, the Holocaust is, in many ways, an uncomfortable part of world history. As an event that many are eager to forget, or would rather ignore, the process of memorializing the Holocaust faces significant challenges. Moreover, distance in terms of space and time from the events of the Holocaust makes constructing a memorial to the atrocity in a place removed from the immediacy of the event itself problematic.

Harold Marcuse argues that the process of Holocaust memorialization is marked by three stages: those memorials created or first planned while the Holocaust was still happening; monuments created or proposed by survivors shortly after being liberated; and lastly, "the transition to a new phase in which survivors and states worked together" to create memorials in light of the destruction of Holocaust sites. ${ }^{1}$ Moreover, while initial Holocaust memorials reflected "the tradition of funerary monuments and war memorials," two styles later became prevalent: "first, expressionistic, heroic realism [...] and slightly

\footnotetext{
${ }^{1}$ Harold Marcuse, "Holocaust Memorials: The Emergence of a Genre," The American Historical Review 115 (February, 2010): 55.
} 
later, a more abstract avant-garde tradition." ${ }^{2}$ The search for Holocaust symbolism was also significant, but problematic, since symbols associated with Jewish identity drew criticism throughout much of the world for some time after the Holocaust. ${ }^{3}$ Aside from the issue of developing a lexicon of Holocaust symbols, however, the process of memorialization itself raises issues that need to be acknowledged.

One of the problems of memorializing the Holocaust is inherent in the flaws of memorialization itself: while we may go through the process of memorializing with the intent of preserving the memory of an event for the future, memorials may actually work to help us forget. James Young has elaborated on this very issue, arguing that "once we assign monumental form to memory, we have to some degree divested ourselves of the obligation to remember," and so monuments may actually work to "relieve viewers of their memory burden." ${ }^{4}$ This becomes especially problematic given that many argue that the value of learning about the Holocaust is found in preventing similar atrocities from occurring in the future. Then again, given the dark and uncomfortable nature of the event itself, memorialization also becomes a means of forgetting by ascribing the 'burden of remembrance' onto memorials.

By divesting the responsibility for remembrance onto traditional static memorials, the event in question also loses impact on the present. Dan Stone is aware of this issue, arguing that "for remembrance to be meaningful it must have an effect on the politics of the present, and not merely be the mouthing of empty slogans - 'never again!' - or enactment

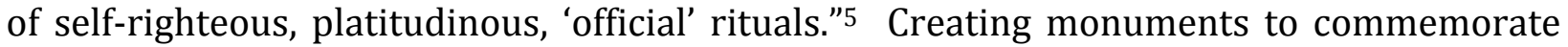
the Holocaust is thus problematic, especially given that national governments typically support processes of memorialization that "affirm the righteousness of a nation's birth," or reinforce grandiose conceptions of a nation's past and its struggle for greatness. ${ }^{6}$ Given the typically celebratory place of monuments in terms of national history, the problem for states that were complicit in perpetrating and collaborating in the events of the Holocaust becomes one of confronting a criminal past that does not easily lend itself to redemption. ${ }^{7}$

The complicated process of Holocaust memorialization in the post-Communist states of Eastern Europe illustrates some of the unique challenges of memorializing a past that many are eager to forget, especially in light of constructing a new national identity separate from that of the Soviet Union. Memorialization of the Holocaust for postCommunist states was a difficult process because it raised "questions of how the preCommunist state treated their Jewish citizens before, during, and even after the war years," with many states having eagerly collaborated with the Nazis in orchestrating the Holocaust. ${ }^{8}$ Thus, in attempting to reinvigorate their past to forge a new national identity separate from the yoke of Communism, these states were now confronted with their own

\footnotetext{
2 Ibid., 88.

3 Ibid., 62.

${ }^{4}$ James Young, The Texture of Memory: Holocaust Memorials and Meaning (New Haven: Yale University Press, 1993), 5.

5 Dan Stone, History, Memory and Mass Atrocity: Essays on the Holocaust and Genocide (London: Vallentine Mitchell, 2006), 150.

${ }^{6}$ James E. Young, "The Counter-Monument: Memory Against Itself in Germany Today," Critical Inquiry 18 (Winter, 1992): 270.

7 Ibid.

${ }^{8}$ Jeffrey Blutinger, “An Inconvenient Past: Post-Communist Holocaust Memorialization," Shofar 29 (2010): 74.
} 
regrettable involvement in the Holocaust, complicating how the event would be commemorated.

Jeffrey Blutinger argues that three distinct trends emerged out of the process of memorializing the wartime past of the post-Communist states in light of their involvement in the Holocaust: "aphasia," an attempt to avoid the Holocaust altogether or in part; "deflective negationism," an attempt to allocate blame for the Holocaust unto others or downplay the event; and "an open examination of the Holocaust and the role that the local population played in it," with states typically shifting towards this trend. ${ }^{9}$ Ultimately, under Communist rule, the Holocaust had been depicted as part of fascist aggression against the Soviet Union, while victims were associated with fascist resistance rather than Jewish identity. ${ }^{10}$ Indeed, it was typical of Soviet monuments dedicated to the Holocaust to celebrate themes of heroism and resistance, as well as the collective rather than commemorate the victims of the event. ${ }^{11}$

Perhaps the greatest example of the valorizing style typical of Soviet monuments is Nathan Rapaport's Warsaw Ghetto Monument. Initially turned down by Stalin's government for being "too Jewish," illustrating the desire to commemorate a collective identity, Rapaport's monument nevertheless celebrated the Jewish resistance movement that brought about the Warsaw Ghetto Uprising, an event that does lend itself to romanticization. ${ }^{12}$ However, the most striking feature of the monument was its intense connection to the event, occupying a place of significance within the former ruins of the Warsaw Ghetto, and so becoming "less an aesthetic reference to events than a part of them."13 By constructing the monument on the site of the event itself, the monument became all the more empowered, spatially inseparable from that which it was designed to commemorate.

Holocaust monuments may derive power from being situated near to particular sites of significance for those who experienced the event. Sites of this kind include former concentration camps, death camps, and ghettoes. Spatial placement presents a problem when situating a monument outside of the immediacy of such spaces. Herein lies a problem in creating a Holocaust monument in Calgary: the city is far removed geographically from the events of the Holocaust itself, and is also temporally distant. Thus, a criticism of the need for a Holocaust memorial in Calgary is one of a perceived lack of urgency. Moreover, as part of the Canadian war effort during the Second World War, and thus part of the liberation of those enslaved to Nazi tyranny, many in Calgary may feel that a Holocaust memorial is unnecessary, more fitting as an expression of guilt for areas closer to perpetrators and victims of the genocide.

Even for those places more immediately connected to the legacy of the Holocaust, memorialization often becomes an exercise in displacing guilt. Attempts to sidestep this uncomfortable past are evident with the case of Holocaust memorialization in Hamburg. With the dawn of the postwar period, the idea that Hamburg had not been particularly supportive of the Nazi regime, given its liberalism and support of socialism, became

\footnotetext{
9 Ibid., 76-77.

10 Ibid., 74.

11 Marcuse, “Holocaust Memorials," 80.

12 James E. Young, “The Biography of a Memorial Icon: Nathan Rapoport's Warsaw Ghetto Monument,"

Representations 26 (Spring, 1989): 80.

13 Ibid., 83.
} 
prevalent as a means of dismissing responsibility for the past. ${ }^{14}$ As a consequence, Holocaust memorialization was marked by "ambivalence towards [Hamburg's] murdered Jewish citizens, along with an absence of responsibility for the crimes." 15 Strangely, even the development of a counter-monument to the fascist-inspired $76^{\text {th }}$ Infantry Regiment monument "does not pay tribute to [Hamburg's] former Jewish citizens; instead, it attests to the victimization of Germans." 16 This focus on victimizing Germans thus becomes a way of avoiding responsibility for the Holocaust by shifting the focus from the Jewish victims to German victims of Allied bombing campaigns.

Traditional monuments for memorialization thus present very real issues for perpetuating memory in future generations, often displacing or eroding memory, or divesting the present of responsibility for the past. Indeed, these problems have given rise to counter-monuments, which attempt to address the issues of traditional monuments: "Instead of searing memory into public consciousness [...] conventional memorials seal memory off from awareness altogether." 17 Thus, the goals of counter-monuments are many: "not to console but to provoke; not to remain fixed but to change... not to be ignored by its passerby but to demand interaction," and, most audaciously, "not to accept graciously the burden of memory but to throw it back at the town's feet."18 Ultimately, countermonuments are designed to challenge traditional forms of memorialization and its problems, and force discussion and interaction as a means of keeping memory persistent in the present.

Counter-monuments nevertheless run into many of the same problems as traditional monuments in memorialization, however. The focus on the temporary character of counter-monuments is one issue that is problematic given that, while a "consequence of a memorial's unyielding fixedness in space is also its death over time" in relation to traditional static monuments, so too will counter-monuments be forgotten once they no longer occupy space at all. ${ }^{19}$ The problem of fixed monuments being forgotten as a part of everyday life also applies to permanent counter-monuments as well. Countermonuments as a form of memorialization are just as susceptible to many of the issues that face traditional monuments, especially the all-powerful decaying effect of time, which works to gradually erode significance and meaning: "the immortalization of memory in stone lends towards a process of distancing and forgetting." 20 Eventually, things become commonplace and may lose their power, and counter-monuments are no exception to this.

The desire to displace guilt and blame for the Holocaust is irrevocably tied to the uncomfortable legacy of the event, and is not simply a phenomenon of memorialization in areas tied more directly to the events of the Holocaust itself. Indeed, just as Rapaport's Warsaw Ghetto Monument was largely a valorizing representation, other Holocaust

\footnotetext{
${ }^{14}$ Natasha Goldman, "Marking Absence: Remembrance and Hamburg's Holocaust Memorials," in Beyond Berlin: Twelve German Cities Confront the Nazi Past, eds. Gavriel D. Rosenfeld and Paul B. Jaskot (Ann Arbor: University of Michigan Press, 2010), 255-56.

15 Ibid., 256.

16 Ibid., 259.

17 Young, "The Counter-Monument," 272.

18 Ibid., 277.

19 Ibid., 294.

20 Time Cole, Selling the Holocaust, From Auschwitz to Schindler: How History is Bought, Packaged, and Sold (New York: Routledge, 1999), 5.
} 
representations have tended to focus on uplifting narratives rather than face the dark character of the sinister event itself. This problem can be seen in what Lawrence L. Langer referred to as "the Americanization of the Holocaust," a refusal to deal with the fact that "the history of the Holocaust" is one of human beings dying for nothing, regardless of choice, an uncomfortable notion. ${ }^{21}$ Thus, representations in America have tended to focus on "the Holocaust as a moral event with a "happy ending,"' such as Schindler's List and The Diary of Anne Frank, rather than face the "catastrophic and apocalyptic" character of the event that nearly annihilated European Jewry. ${ }^{22}$

Thus, the great challenge becomes attempting to accurately represent the exceptionally destructive and painful character of the Holocaust head-on. To attempt to sidestep, dilute this reality, or to emphasize stories of courage and heroism in relation to the Holocaust is ultimately a misrepresentation, contributing to the erosion of public memory of the true nature of the event. ${ }^{23}$ Representation becomes the way that events are remembered for subsequent generations, and so it is important to remember the ways in which representation can shape memory, and its susceptibility to distortion and misrepresentation. ${ }^{24}$ Ultimately, memorialization, being a form of representation, is no different, and subject to the same problems. These problems were very much at the forefront of our decision-making process in taking on the arduous task of constructing our own memorial to the Holocaust in Calgary.

First, our monument is dedicated to all victims of the Holocaust. We felt that this was important because, while we do have a Jewish community in Calgary, we felt it best to not single out any specific group. This decision was not taken lightly, and we understand that not solely identifying Jews as victims of the Holocaust can be problematic, since they were undoubtedly the largest group of victims that perpetrators targeted. Nevertheless, it is important that we remember that no life wrongly taken is more important than the next: the tragedy of the Holocaust is that is was an event of unparalleled brutality perpetrated by people against people, and dedicating it to a specific group within the varied identities of victims, brings problems of its own that we felt would best be avoided for our purposes. Moreover, by leaving it open to all victims, the onus is left on the observer to remember who the victims were, also tapping into a wider possibility for personal connections through family history and association with the event of the Holocaust itself, and Calgary's cultural diversity.

The most troubling issue of identification is that of exclusion: choosing to identify only select groups of victims inevitably leads to the exclusion of other victims. On the other hand, purposely choosing to identify every victim group is also problematic, not only because of how many 'different' victim groups were affected by the travesty of the Holocaust, but also because not every victim necessarily falls into neat and tidy categories. The lines of identity can be very blurry to say the least. Also, by attempting to categorize victims into specific identity groups, we are assuming that these victims can be defined by labels they themselves may not have necessarily identified with. In light of these problems

\footnotetext{
${ }^{21}$ Lawrence L. Langer, "The Americanization of the Holocaust on Stage and Screen," in Admitting the Holocaust: Collected Essays, ed. Lawrence Langer (New York: Oxford University Press, 1995), 157.

22 Anson Rabinback, "From Explosion to Erosion: Holocaust Memorialization in America since Bitburg," History and Memories 9, no. 1 (Fall, 1997): 227.

23 Ibid.

${ }^{24}$ Robert Getso, “Revisiting Holocaust Memorialization," Peace Review 19, no. 2 (April-June, 2007): 251.
} 
associated with identity and memorialization, we chose to stay silent on the issue and instead simply dedicated our monument to all victims of the Holocaust. Admittedly, however, specific groups of people were targeted by the perpetrators of the Holocaust, and the choice to avoid identifying these groups may erode public awareness of this important fact.

As was already discussed, the issue of location is important not only given the distance of Calgary spatially and temporally from the event, but also in consideration of accessibility for viewers in Calgary. Early on in the design process, we debated several different locations, the first being near the Military Museums beside Crowchild Trail and near Mount Royal University. At first, we felt as though a location near the Military Museums would make sense, because the Holocaust was a significant event of the Second World War. However, we eventually discarded this idea as we realized that, rather than becoming empowered by proximity to the Military Museums, our Holocaust monument would likely be subsumed and its significance displaced by the museum's representation of Canadian military prowess: a message we do not want mixed up with our monument.

The second location we considered was in Riley Park near the corner of $12^{\text {th }}$ street NW and $8^{\text {th }}$ avenue NW, adjacent to the popular community of Kensington. ${ }^{25}$ This location was appealing because of the popularity of the park, and the adequate space for the monument. We later rejected this location for several reasons. The first issue was the proximity to a children's play ground, which would bring grounds for criticism from concerned parents. The second issue is locating the monument to one residential neighborhood might imply that the neighborhood specifically was more attached to the Holocaust in particular. Finally, the location was also very close in proximity to a Christian church and a public elementary school; we felt it was an innapropriate place for our monument, so close to either of these institutions.

We eventually decided that a downtown location would be more appropriate to avoid singling out a particular community for the burden of responsibility for our monument, and because the diversity of downtown is in some ways in line with our desire to dedicate the monument to all victims of the Holocaust rather than one particular group. While we initially looked at a few spots in Prince's Island Park, we found that adequate sites already had benches dedicated to memorializing loved ones, and were also close to children's playgrounds as well. Moreover, the park itself is also more thematically centered on local history, so our monument would not fit into this theme. Ultimately, we decided on a site on the South side of the Bow River along the Bow River Pathway directly across from the Peace Bridge.26 This site played perfectly into our desire for a downtown, central location, and also a high-traffic area.

In terms of design, we will have fifteen feet of mock train tracks made out of concrete, wood, metal for the rails, and gravel. Train tracks have become a powerful symbol of the Holocaust, and our use is meant to represent the finality of the Holocaust for the vast majority of the victims. For many, there was one way into the camps, and only one way out. The train tracks will lead observers to the monument from the adjacent walkway in a way reminiscent of the experience of many victims in the Holocaust who were transplanted from normalcy to the brutal life of the camps by train and cattle car.

${ }^{25}$ See Appendix I.

${ }^{26}$ See Appendices II and III. 
Furthermore, our use of train tracks, positioned near a popular walkway in downtown Calgary, metaphorically connects the past of the event of the Holocaust itself to the everyday present.

The actual monument will be surrounded by a ring of concrete about three and a half feet in diameter surrounding the concrete base of the figures. The inscription in the base bolted in steel will read, "Dedicated to All Victims of the Holocaust Perpetrated Under Nazi Tyranny." The concrete surrounding the base will be made deliberately uneven to convey an uneasy sense of discomfort for observers. It is likely that the observer will also be unsure of why they are left feeling uneasy, adding to the discomfort conveyed. This feeling of discomfort is an important part of our monument, and we thought it better to embrace the uncomfortable rather than try to whitewash or displace it, as in prior discussed instances. Thus, the uneven ground becomes a way of subtly reinforcing the overall feeling we want our monument to convey: recognizing that the Holocaust is such an unsettling event is important to better understanding it.

In more specific terms of design, the monument will consist of five figures, each representative of a victim of the Holocaust. The figures will be situated upon a raised platform made of concrete about five feet in diameter and three feet high. Each of these human-like figures will portray a different and distinct emotion through the use of facial expression and body language. While the emotion that each figure conveys will be unique, we are not trying to imply that the victims never felt various combinations of emotions at one particular time. Instead, we wish to convey a variety of emotions to represent how the victims must have felt at various stages and in differing circumstances throughout the Holocaust. For example, The Diary of Dawid Sierakowiak evidences the broad range of emotions victims of Nazi brutality felt throughout their experience. Dawid, the diary writer, is at varying times angry, confused, and depressed by his experience. We felt that including a variety of emotions also reminds the viewer that the experiences of the victims of the Holocaust were diverse. ${ }^{27}$

While the five figures will occupy the same platform, they will not be interacting with one another, except for one figure who interacts with a child. The figures' lack of interaction symbolizes the sense of isolation many victims endured. Indeed, while the Holocaust was arguably a collective experience for many, psychological and physical isolation were nevertheless important factors as well. To reinforce the sense of the isolating experience of the Holocaust, the figures will also be wrapped in barbed wire, symbolizing the confining imprisonment of camp and ghetto life, and the traumatic nature of the event itself for the individuals who had the misfortune of experiencing it. The use of barbed wire on the bare flesh of the victims speaks to the fact that the Holocaust left deep scars on those who lived through it, the trauma becoming a regrettable part of everyday life, reminiscent of Langer's sense of durational time and Holocaust experience, as well as the character of Rosa in Cynthia Ozick's The Shawl.

The emotions we chose to convey through the figures are anger, fear, grief, indifference, and a sense of defeat akin to Primo Levi's conception of 'the drowned' in his book Survival in Auschwitz. While the emotions will be displayed to appear distinctly recognizable for observers, they will not be so exaggerated as to allow sentimentality to

\footnotetext{
27 Dawid Sierakowiak, The Diary of Dawid Sierakowiak: Five Notebooks from the Lodz Ghetto, ed. Alan Adelson,
} trans. Kamil Turowski (New York: Oxford University Press, 1996). 
overpower the intended effect of the monument. Indeed, according to Yair Mozar, the trauma of the Holocaust represents "the greatest and deepest quarry of emotions ever known since the distant, misty dawn of humanity," a theme that we sought to incorporate into our memorialization. ${ }^{28}$ In terms of the figures themselves, they will be made to appear androgynous, naked, and somewhat emaciated and distorted, alluding to the destruction of identity and humanity that victims suffered.

The figure of indifference will be shown standing upright, facing away from the other figures. Indifference is not meant to convey a sense of ignorance or uncaring. Rather, it shows how the trauma of the experience of the Holocaust at times enveloped the emotional power of the individual, descending into the experience in a way akin to Levi's idea of 'the saved': those who buried their emotions and accepted what they had to do to survive. The figure of fear will be positioned lurched over with hands in the air in a protective gesture, as if in an attempt to stave off harm. The figure of anger will be upright, attempting to defiantly rip away the barbed wire that covers the body, in an act meant to parallel acts of resistance. It will also reflect the constricting reality of the Holocaust over those who were simply unable to direct their malice against those who violated humanity.

The figure depicting grief is different from the others; it will be depicted holding onto a smaller, limp figure. The smaller figure is a child, and is perhaps dead or injured. This is meant as a reminder that the Holocaust was perpetrated against peoples of all ages, and destroyed the integral fabric of the family structure. Because of gender stereotypes, it is likely that people would assume that the grief-stricken figure is a mother. However, in attempting to negotiate this and keep the figures perceived as androgynous, the figure of grief will be bent down on one knee and have arms wrapped around the child, the intent being a more gender-neutral position than others that we had debated.

Finally, the figure of 'the drowned' will be positioned on its knees, with head tilted to the side in a portrayal of the loss of all willpower under the crushing experience of the Holocaust. This figure is meant to elicit a sense of the rhetoric of the unimaginable that is so often applied to the Holocaust. It reflects the idea being that the event was so abhorrent and traumatic that we in the present simply cannot understand the experience of those who lived it. For Levi, 'the drowned' were those who had lost the will to continue in the humanity-destroying system of 'the Lager,' an uncomfortable notion that does not easily lend itself to romanticization or redemption. In speaking of 'the drowned' in one passage, Levi alludes to the horrific scar that the reality of 'the Lager' had left on him:

they crowd my memory with their faceless presences, and if I could enclose all the evil of our time in one image, I would choose this image which is familiar to me: an emaciated man with head dropped and shoulders curved, on whose face and in whose eyes not a trace of a thought is to be seen. ${ }^{29}$

To ensure the monument's physical longevity, it will be constructed of iron, and the barbed-wire wrapped around the individuals will be real barbed wire. This was a conscious decision, because the barbed wire serves to protect the figures of the monument

28 Yair Mozar, Israeli Poetry of the Holocaust (Cranberry: Rosemont Publishing, 2008), 157.

${ }^{29}$ Primo Levi, Survival in Auschwitz, trans. S. Woolf (Toronto: Touchstone, 1996), 90. 
from vandalism and will also prevent people from climbing onto the raised platform with the figures, helping to ensure that the monument will be respected. Of course, the use of real barbed wire is a potential source of danger, but the monument itself will not encourage people to climb onto it, nor will doing so be particularly easy; therefore injury on the barbed wire would take some concerted effort on the part of individuals. As for the continued maintenance of the monument, it would fall under the City of Calgary Parks Department due to the location of the monument within the Peace Park area. Within the Park's Department's annual reports, a budget is set that includes tasks of environmental management that would include weed and pest control, and urban forest management as per the Agricultural services of the city bylaws. ${ }^{30}$

In deciding upon conveying a feeling of uneasiness, we felt that Stone's assertion that "no starker characteristic of 'uncertain' times can be found than genocide" was astute. ${ }^{31}$ Uncertainty and uneasiness are important characteristics wrapped up in understanding the Holocaust and, as for many victims, the perpetrators went to great lengths to ensure that understanding and comfort were not permitted, practicing intricate deceptions to placate their prey. While we do not want and are unable to recreate the feelings that the victims themselves must have felt in the experience of the Holocaust, our conveyance of discomfort is meant to parallel the trauma that the Holocaust has left on the Western. ${ }^{32}$

Although our monument is strategically placed in an area close to other monuments, we are not attempting to express any ideas of redemption, despite the proximity of the monument to the infamous Peace Bridge. As Langer asserts, to attribute false and comforting values from representations of the Holocaust "leads us from the uncharted waters of that atrocity back into the safe channels of a sheltered world," displacing the true nature of the event. ${ }^{33}$ However, it is not our intention to have the design of the monument evoke feelings of guilt in the observer, and is not meant to remember only the violence, terror, and destruction of the Holocaust. ${ }^{34}$ Rather than have observers simply view the monument, feel uncomfortable, and subsequently walk away, our monument is meant to evince feelings from the viewer compounded by the private and semi-secluded feel it will have because of the surrounding trees.

Regarding the issue of the monument's proximity to the Peace Bridge, we argue that the monument, by this juxtaposition, will logically create an appreciation for the peace that we have been afforded in Calgary. However, in some ways the monument will also work similarly to a counter-monument by bringing up questions of time and place in relation to the event of the Holocaust itself. By being close to the nearby Peace Grove and the Peace Bridge, it is our desire that the viewer will question the ideas of peace perpetuated by these monuments. Indeed, while the Holocaust was anything but a peaceful event, one must remember that Calgary itself was not devastated by the ruin of the Second World War or

\footnotetext{
30 The City of Calgary, "Annual Report, 1991," 15. http://www.calgary.ca/CA/cityclerks/Documents/Corporate-records/Archives/Parks-Department-Annual-Reports/Annual-Report1991.pdf

31 Stone, "Holocaust Memory, Memorials and Museums," 149.

32 David Clary Large, Berlin (New York: Basic Books Publishing, 2000), 528.

33 Lawrence L. Langer, "Beyond Theodicy: Jewish Victims and the Holocaust," in Admitting the Holocaust: Collected Essays (New York: Oxford University Press, 1995), 25.

${ }^{34}$ Stone, "Holocaust Memory, Memorials and Museums," 150.
} 
the Holocaust. Nevertheless, despite Calgary's 'peaceful' existence in these times, the atrocity of the Holocaust was still being perpetuated. Thus, in a sort of counter-monument fashion, our monument should elicit questions about the nature of peace across the world despite the persistent blessing of peace in Calgary.

Much the same can be said about the numerous other atrocities committed across the world in the wake of the Holocaust, the likes of ethnic cleansing in Yugoslavia and Rwanda for example. It is important to remember that, while Calgary is and has been peaceful, abhorrent acts are nevertheless perpetrated in other parts of the world. It is by facing the terrible reality of the Holocaust through our memorialization that we aim to "find a way of restoring to the imagination of coming generations the depth and scope of the catastrophe." 35 Indeed, peace in Calgary is a blessing, but an extensive and sophisticated concentration camp system is still perpetrated in the totalitarian state of North Korea, a reminder that all is not well in the world despite our good fortune. Our monument does not propose to solve or pretend to offer a solution to the ills of the world. Rather, it is designed to remind generations of Calgarians now and in the future that the world has not learned from the tired 'never again' rhetoric of the Holocaust.

While all types of historical monuments should be thoughtfully planned, a monument memorializing the Holocaust demands exceptionally thorough attention and consideration. The nature of the Holocaust itself is particularly difficult to understand, comprehend, and represent, making memorialization of the event problematic. Due to the particularly uncomfortable subject of the Holocaust, monuments dedicated to the event have often been crafted as a means of placating discomfort or displacing guilt. After careful consideration of the many problems associated with Holocaust memorialization, our monument is designed to confront and recognize the uncomfortable reality of the Holocaust as a horrendous event in Western Civilization and human history. By doing so, we aim to elicit a sense of appreciation for the nature of peace in Calgary, as well as to problematize that peace.

35 Lawrence L. Langer, "What More Can Be Said About the Holocaust?” in Admitting the Holocaust: Collected Essays, ed. Lawrence L. Langer (New York: Oxford University Press, 1995), 180. 


\section{Appendices}

1. Location Across from Peace Bridge- Actual Location. Source: authors' photograph.

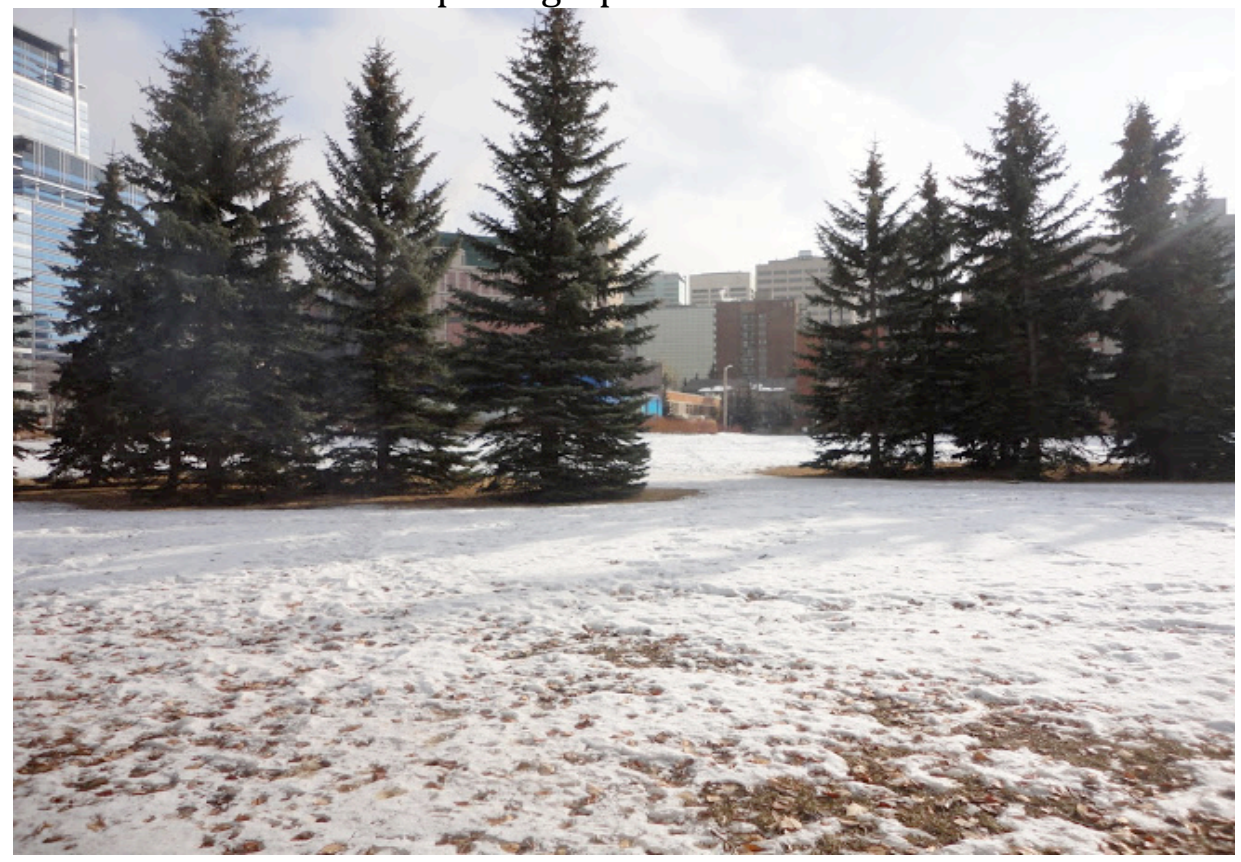

2. Location as seen from the Peace Bridge. Source: authors' photograph.

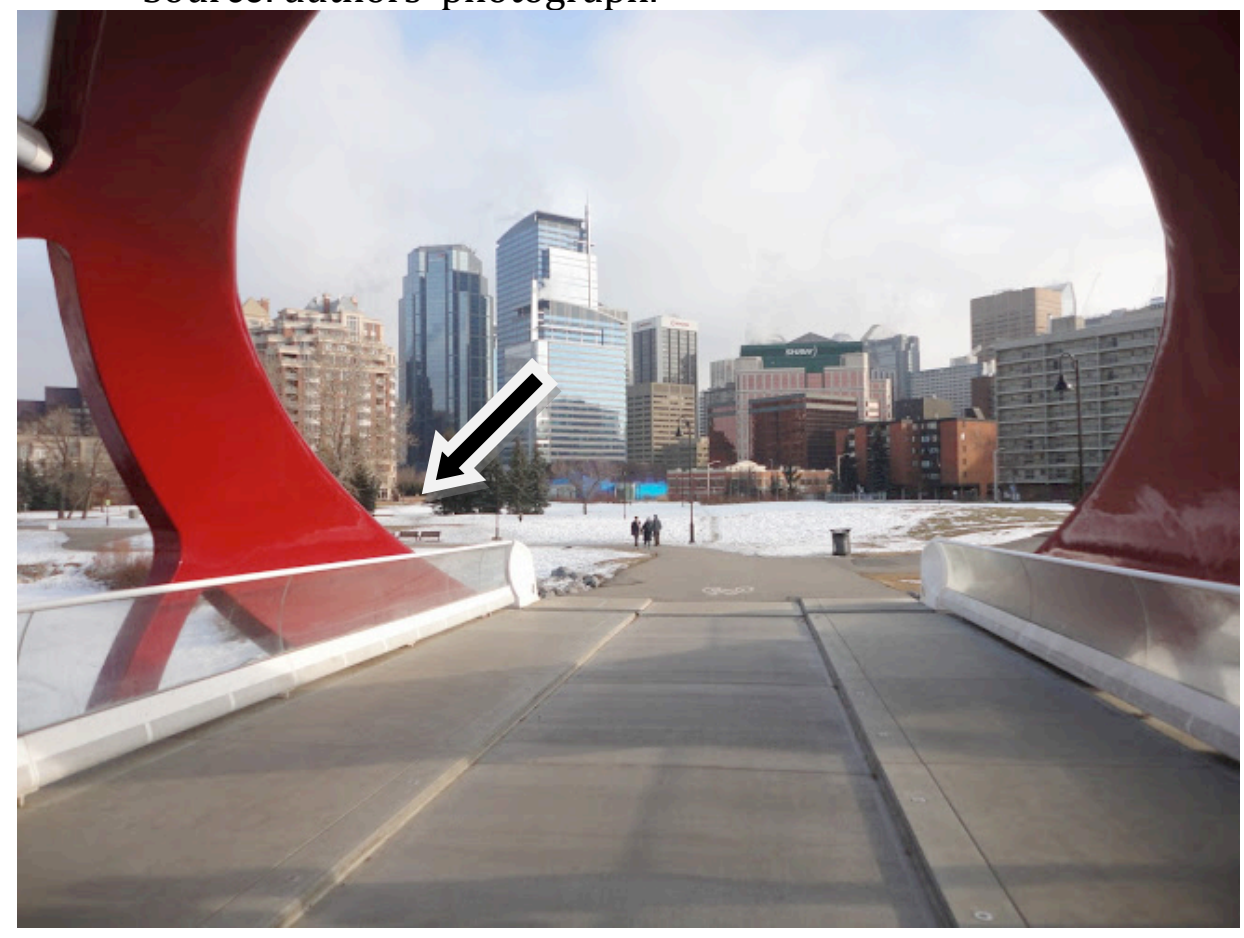




\section{Bibliography}

Blutinger, Jeffrey. "An Inconvenient Past: Post-Communist Holocaust Memorialization." Shofar, 29 (2010): 73-94.

Cole, Tim. Selling the Holocaust, From Auschwitz to Schindler: How History is Bought, Packaged, and Sold. New York: Routledge, 1999.

Getso, Robert. "Holocaust Memorialization Revisited." Peace Review 19, no. 2 (April-June, 2007): 247-253.

Goldman, Natasha. "Marking Absence: Remembrance and Hamburg's Holocaust Memorials." In Beyond Berlin: Twelve German Cities Confront the Nazi Past. Gavriel D. Rosenfeld and Paul B. Jaskot, eds. Ann Arbor: University of Michigan Press, 2010. 251-272.

Langer, Lawrence L. Ed. Admitting the Holocaust: Collected Essays. New York: Oxford University Press,1995.

Large, David Clary. Berlin. New York: Basic Books Publishing, 2000.

Levi, Primo. Survival in Auschwitz. Translated by Stuart Woolf. Toronto: Touchstone, 1996.

Marcuse, Harold. "Holocaust Memorials: The Emergence of a Genre." The American Historical Review, 115 (February, 2010): 53-89.

Mozar, Yair. Israeli Poetry of the Holocaust. Cranberry: Rosemont Publishing, 2008.

Rabinbach, Anson. "From Explosion to Erosion: Holocaust Memorialization in America since Bitburg." History and Memories, 9, no. 1/2 (Fall, 1997): 226-255.

Sierakowiak, Dawid. The Diary of Dawid Sierakowiak: Five Notebooks from the Lodz Ghetto. Edited by Alan Adelson. Translated by Kamil Turowski. New York: Oxford University Press, 1996.

Stone, Dan. "Holocaust Memory, Memorials and Museums." In History, Memory and Mass Atrocity: Essays on the Holocaust and Genocide, 148-173. London: Vallentine Mitchell, 2006

The City of Calgary. "Annual Report, 1991." 1-78. http://www.calgary.ca/CA/cityclerks/Documents/Corporate-records/Archives/Parks-Department-AnnualReports/Annual-Report-1991.pdf

Young, James E. "The Biography of a Memorial Icon: Nathan Rapaport's Warsaw Ghetto Monument." Representations, 26 (Spring, 1989): 69-106. 
- - — "The Counter-Monument: Memory Against Itself in Germany Today." Critical Inquiry, 18 (Winter, 1992): 267-296.

. The Texture of Memory: Holocaust Memorials and Meaning. New Haven: Yale University Press, 1993. 